\title{
MORPHOLOGY AND ANATOMIC-SURGICAL SEGMENTATION OF THE SPLEEN OF Pecari tajacu LINNAEUS, 1758
}

\author{
MORFOLOGIA E SEGMENTAÇÃO ANÁTOMO-CIRÚRGICA DO BAÇO DE Pecari \\ tajacu LINNAEUS, 1758
}

\author{
Gleidson Benevides de OLIVEIRA ${ }^{1}$; Felipe Venceslau CÂMARA ${ }^{\mathbf{1}}$; \\ Ferdinando Vinícius Fernandes BEZERRA ${ }^{1}$; Hélio Noberto de ARAÚJO JÚNIOR ${ }^{1}$; \\ Radan Elvis Matias de OLIVEIRA ${ }^{\mathbf{1}}$; Herson da Silva COSTA ${ }^{1}$; Amilton Cesar SANTOS ${ }^{2}$; \\ Carlos Eduardo Bezerra de MOURA ${ }^{1}$; Moacir Franco de OLIVEIRA ${ }^{1}$ \\ 1. Center of Agrarian Sciences, Universidade Federal Rural do Semi-Árido - UFERSA, Mossoró, RN, Brazil. \\ gleidson_benevides@hotmail.com; 2. Department of Anatomy of the Domestic and Wild Animals, School of Veterinary Medicine and \\ Animal Science, University of São Paulo - USP, São Paulo, SP, Brazil.
}

\begin{abstract}
The spleen is a secondary lymphoid organ with importance in clinical surgery. Due this and the lack of data in the literature, the current paper analyzes the organ's morphology and segmentation in collared peccaries. Twenty animals were used at the Center for the Multiplication of Wild Animals of the Universidade Federal Rural do SemiÁrido, Mossoró RN Brazil. The spleen was removed with the splenic pedicle preserved, identifying the lineal artery and vein. Fragments from four spleens were harvested to be examined under light microscopy. They were fixed in a paraformaldehyde solution $4 \%$ and buffered with sodium phosphate $0.1 \mathrm{M}, \mathrm{pH} 7.4$. Routine histological techniques were performed: the spleens were dehydrated in increasing ethanol concentrations; diaphanized in xylol; soaked in paraffin; $7 \mu \mathrm{m}$ cuts were obtained and stained by hematoxylin-eosin or Gomori trichrome technique. The intraparenchemal vascularization of sixteen spleens were analyzed by latex or vinilite acetate perfusal of the lineal artery and vein and the organ fixed, respectively, in a water solution of formaldehyde $10 \%$ or immersed in a solution of sulfuric acid $30 \%$. The collared peccary's spleen had a tongue-like shape. Under the microscope, the spleen featured an intermediary type, with a great amount of white pulp, a predominance of red pulp and few trabeculae. The spleen's segments had three different regions, namely dorsal, middle and ventral, in irrigation terms with a possible surgical removal of the dorsal region. Knowledge on the angio-architecture and segmentation of the spleen will be a contribution for surgical procedures in wild species, having a great relevance when partial splenectomy is required.
\end{abstract}

KEYWORDS: Anatomy. Spleen artery. Splenectomy. Surgery. Lymphoid organ.

\section{INTRODUCTION}

The spleen is a secondary lymphatic organ associated to the stomach's greater curvature in domestic mammals (KÖNIG; LIEBICH, 2011) and in experimental models (GERMINARO et al., 1997; SANTOS et al., 2013). Its structure comprises a white pulp region with a lymphatic function and a red pulp region with a vascular function (SANTOS et al., 2013), which, as a rule, is multi-functional, including the formation of blood cells, hemoglobin and iron metabolism, destruction of red blood cells, blood filtration, blood storage, phagocytosis and immunological response. Owing to its importance and to its frequent traumas, studies and techniques on the anatomic and surgical segmentation of the spleen are greatly relevant for partial splenectomy, preserving an immune function of the spleen (CHRISTO, 2005; WU et al., 2012; WANG et al., 2014) based on the organ's previous anatomic evidences, contributing to a greater success in surgical approaches.
Several studies on anatomic segmentation of the spleen in animals are extant in the literature, mainly for the capybara (GERMINARO et al., 1997), white-lipped peccary (REGINATO; MELO, 2004), wild boar (FERNÁNDEZ-LLARIO et al., 2004), ruminants (GUPTA et al., 1982; CARVALHAL et al., 2001; MELO et al., 2011), horse (FOZ FILHO et al., 2013), pigs (SILVA; MARTINS, 2000; SAMPAIO; SAMPAIO, 2006) and rabbit (PIRES et al., 2010), presenting a variable form between the species with fissures at the ventral and caudal borders that reveal the splenic lobes. According to these authors, the spleen is cover by a capsule of connective tissue that emits trabecules to the interior of the organ and own the hilum by which the blood vessels arrive and leave of the organ, while internally it presents a white pulp and red pulp. However, nothing is known about the anatomy and vascularization of this organ in collared peccary.

The collared peccary, classified as an artiodactyl mammal, is distributed from the south of the United States to the south of Argentina. 
According to Sowls (1997), peccaries belong to the Tayassuidae family and are characterized by four toes in the front feet and three toes in the hind feet; small ears and eyes; trumpet-like nose, short tail, and feet proportionally slim when contrasted to the robust body. The uper canines are cutting, welldeveloped and directed downwards. Due to the importance of spleen segmentation for clinical medicine and surgery, current paper focuses on segmentation of the collared peccary because of the lack of data on the species in the literature.

\section{MATERIAL AND METHODS}

In order to conduct this research, we investigated twenty adult collared peccaries (10 females and 10 males), that had been employed in previous experiments. This study was approved by the Institutional Bioethics Committee (Opinion CEUA/UFERSA 23/2015, under the Process 23091.005304/2015-81) at the Center for the Multiplication of Wild Animals (CEMAS/UFERSA), authorized by IBAMA as a scientific breeding society (Register 1478912).

A median longitudinal incision on the linea alba was made to remove the animals' spleen. The incision started from the xiphoid cartilage to the pelvis region, giving access to the abdominal viscera and the exposure of the spleen. The latter was collected together with the stomach and pancreas to preserve the vascular pedicle.

\section{Microscopy}

Four spleen fragments, measuring approximately $0.5 \mathrm{~cm}$, were collected to be examined under light microscopy. They were fixed in paraformaldehyde solution $10 \%$ and buffered with sodium phosphate $0.1 \mathrm{M}$, at $\mathrm{pH}$ 7.4. After being fixed, the fragments were dehydrated in increasing concentrations of ethanol and diaphanized in xylol for inclusion in paraffin. Further, $7 \mu \mathrm{m}$ cuts were obtained and the laminas were stained by hematoxylin-eosin or Gomori trichrome technique according to the methodology already described (TOLOSA et al., 2003).

\section{Vascularization}

The lienal artery and vein were cannulated to inject neoprene latex 650 or a solution of vinilite acetate, for vascular molds. The latex injection was used in ten spleens and the lineal artery was injected with red-stained latex whereas the lienal vein was injected with blue-stained latex according to the technique described by Reginato and Melo (2004). Further, the spleens were fixed in formaldehyde solution $10 \%$ and dissected after 72 hours. The splenic parenchyma of the visceral surface was removed for the visualization of the lienal vessels. Photos of the items were taken after dissection.

In the case of lienal arteries and veins injected with vinilite acetate in ten organs, vinilite acetate stained with red pigment denoted the arterial circuit, whilst vinilite acetate stained with blue pigment denoted the venous circuit. After perfused with the polymer, the items were immersed in a solution of sulfuric acid $30 \%$ till the complete corrosion of the parenchyma. They were then washed in running water to remove the excess of sulfuric acid and splenic parenchyma according to the technique described by Cury et al. (2013). Photos were simultaneously taken to support and illustrate the results.

\section{RESULTS}

\section{Macroscopy of the spleen}

The collared peccary's spleen has a long structure, similar to a tongue, red-colored and fixed to the stomach by the greater omentum and related to the greater ventricular curvature of the right compartment of the gastric ventricle (Figure 1A). It lies on the left cranial abdominal quadrant. The spleen has a ventral and a dorsal extremity, a cranial and a caudal edge; a parietal and a visceral surface (Figure 1B). The lienal hilum lies on the latter, or rather, the entrance to the lienal artery and vein (Figure 1C).

A highly significant layer of fatty tissue in the greater omentum was reported in all the dissected items, which fixes the organ to the greater curvature of the gastric ventricle.

\section{Histology}

The spleen of the collared peccary has a thick capsule formed by a fine layer of the mesothelium, a thick conjunctive tissue, and by two to three layers of smooth muscles (Figure 2A, 2B and $2 \mathrm{C}$ ). The capsule penetrates the organ's parenchyma and forms the trabeculae. 


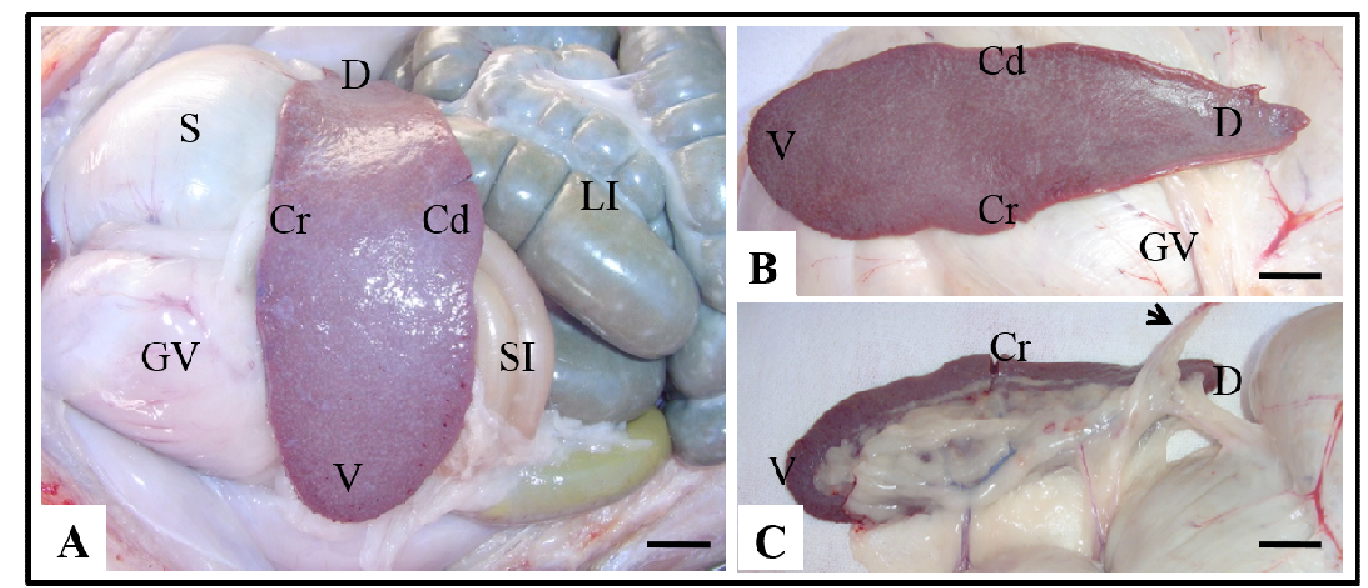

Figure 1. Spleen of the collared peccary seen from the parietal side in A and B, and from the visceral side in $\mathrm{C}$. Anatomic position showing the stomach $(\mathrm{S})$, the gastric ventricle $(\mathrm{GV})$, small intestine (SI), large intestine (LI) and, associated to them, the spleen, the dorsal (D) and ventral (V) extremities; the cranial $(\mathrm{Cr})$ and caudal $(\mathrm{Cd})$ edge; $\mathrm{C}$ : the lienal pedicle (arrow). Fresh material. Bar $=1 \mathrm{~cm}$.

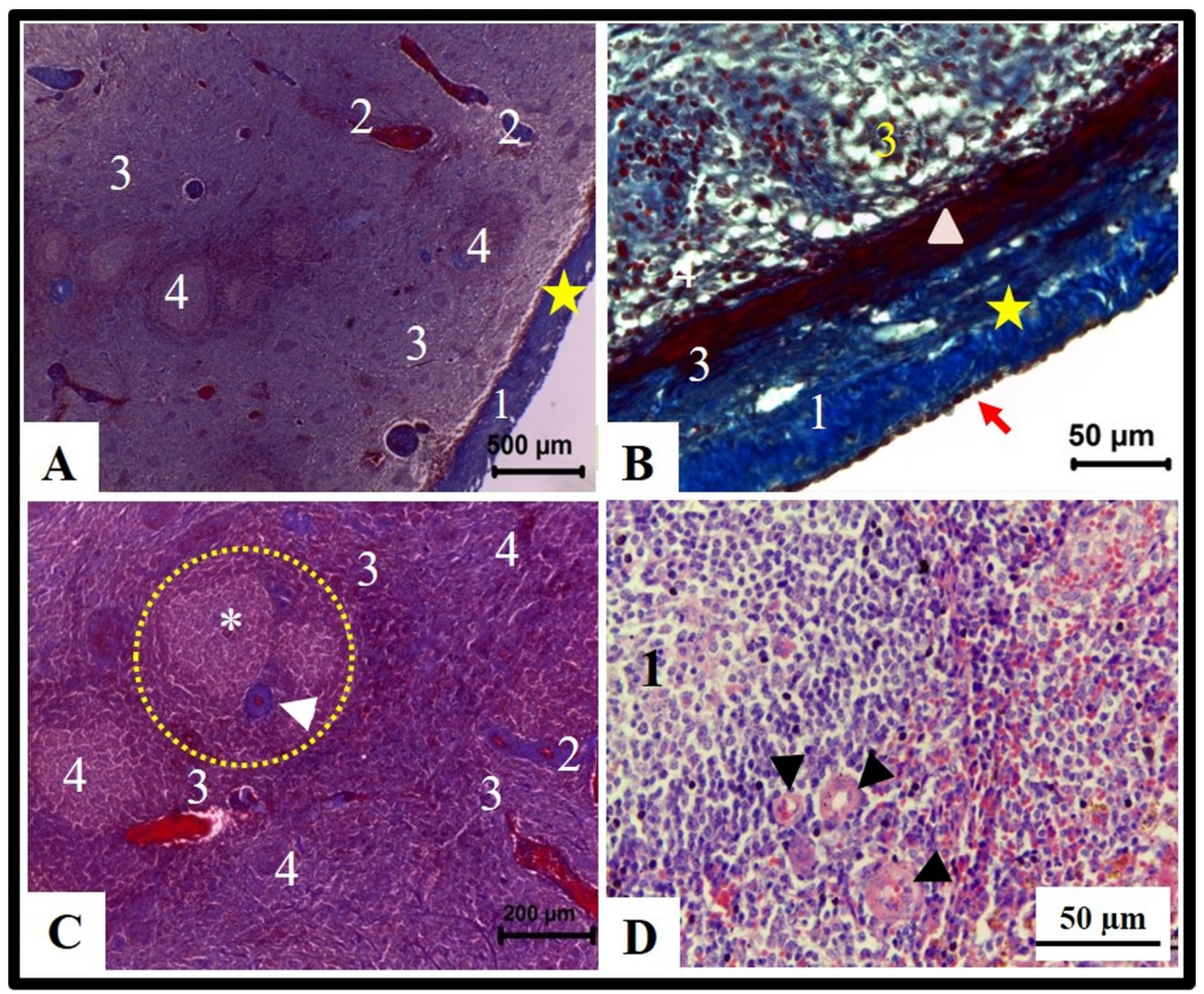

Figure 2. Photomicrograph of the peccary's spleen. A shows the capsule (1) and its thick layer of dense conjunctive tissue (star), trabeculae (2), red (3) and white pulp (4). B shows the capsule (1), with mesothelium (arrow), dense conjunctive tissue (star) and a fine layer of muscular fibers (triangle) and red pulp (3). C shows red pulp (3), white pulp (4) and periarteriole lymphatic sheaths (circle) with a germination center $(*)$, central arteriole (arrow head). D shows periarteriole lymphatic sheath (1) and central or nodular arterioles (arrow heads). Stained by gomori trichrome for A, B, and C; by HandE for D. 
The peccary's spleen parenchyma is divided into white and red pulps (Figure 2A, 2B and 2D). The peccary's white pulp is composed of lymphatic nodules (splenic corpuscles) (Figure 3A) and of areas with thick accumulations of lymphocytes placed around the central or nodular arterioles, called periarterial lymphatic sheaths (Figure $2 \mathrm{C}$ and 2D). On the other hand, the red pulp comprised the most part of the spleen and is formed by reticular fibers (Figure 3B and 3C) and splenic sinuses and cords (Figure 3D) disposed between the white pulp and trabeculae areas. Several erythrocytes may be found in this zone, characterizing the region by the red color of blood. Concentric layers of macrophages (Figure 3D) that surround the capillary ones were also reported in the marginal zone.

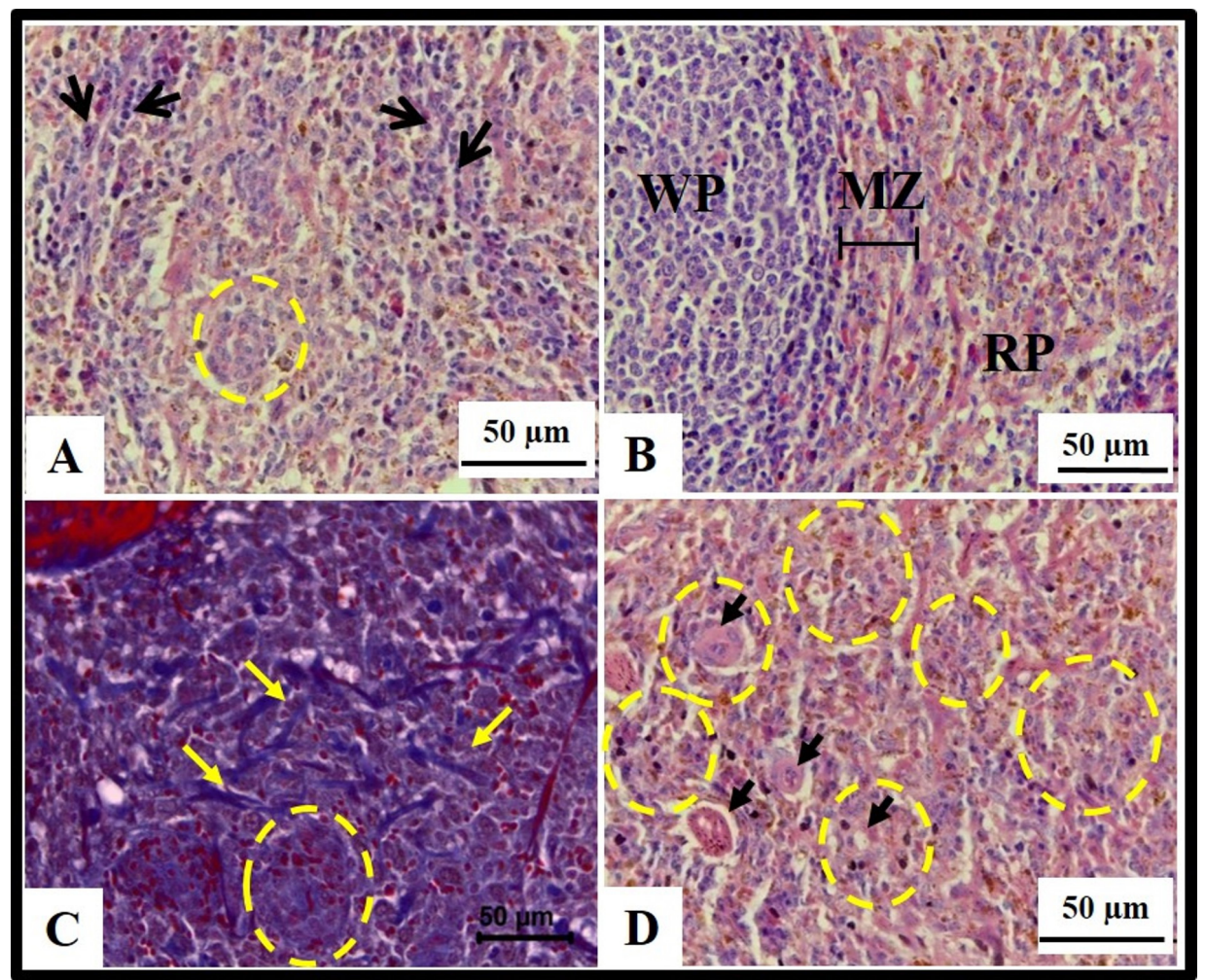

Figure 3. Photomicrograph of the peccary's spleen. A shows splenic cords (arrows) in the red pulp and lymphatic nodule (circle) in the white pulp. B shows white pulp (WP), marginal zone (MZ) and red pulp (RP). C shows red pulp with blue-stained reticular fibers (arrows) and lymphatic nodules (circle) in the white pulp. D shows pericapillary macrophage sheaths, also called ellipsoids (circles) surrounding the blood capillaries (arrow). Stained by HandE for A, B, and D; by gomori trichrome for C.

\section{Vascularization segmentation}

The peccary's lienal artery derives from the division of the celiac artery and soon penetrates the spleen at the hilum region in the visceral side of the region's dorsal extremity and forwards rectilinearly in a dorsal-ventral disposition, branching to the cranial and caudal edges of the spleen. Throughout the trajectory, the vessel discharges a branch that irrigates the dorsal section of the stomach's biggest curvature, namely the cardic part, and goes to the gastric ventricle. Finally, the lienal artery continues as the left gastroepiploic artery, follows the stomach's bigger curvature towards the ventral part and irrigates the fundic section of the stomach, pylorus, the initial part of the duodenum and the pancreas.

The peccary's spleen is divided into three great regions, namely, dorsal, medium and ventral regions. The dorsal section corresponds to that in which the vessels lie before the lienal vein on the left of the organ; the middle section lies between the lienal and the gastroepiploic vessels; the ventral section lies at the right, after the gastroepiploic vessels (Figure 4). 


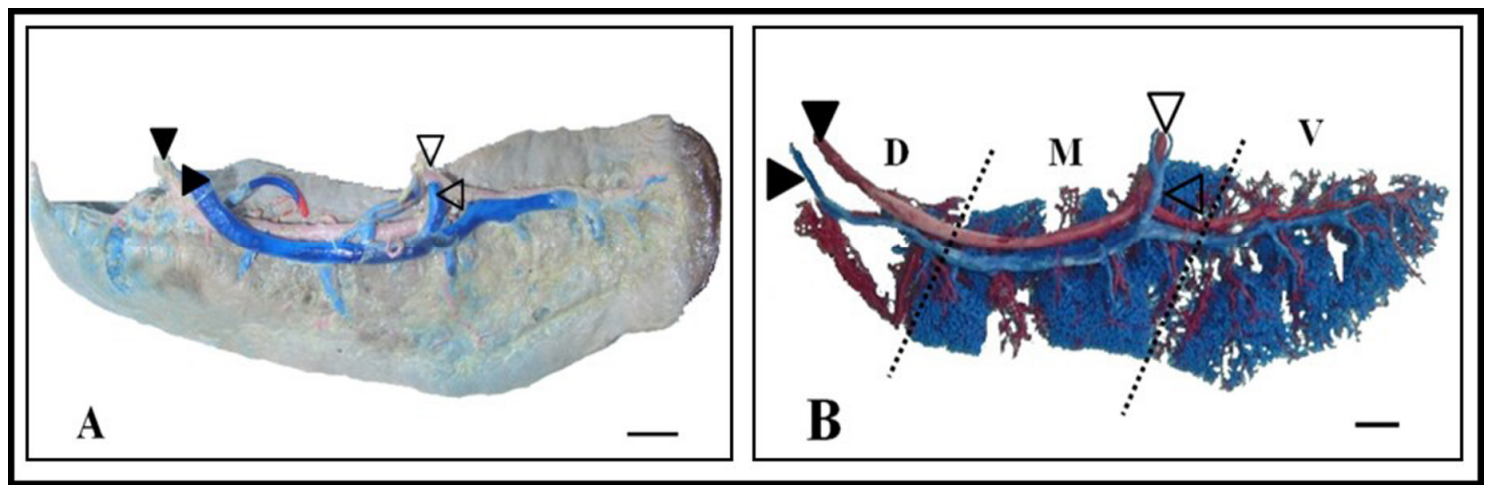

Figure 4. The spleen of the collared peccary. A shows the shape of the spleen from the visceral side. B the visceral view after corrosion. The following structures are provided: gastroepiploic artery $(\boldsymbol{\nabla})$ and vein $(\triangleright)$; lienal artery $(\nabla)$ and vein $(\triangleleft)$; divided by dotted lines, the dorsal (D), media (M) and ventral $(\mathrm{V})$ sections. Injection of blue vinyl acetate in the venous system and red in the arterial one.

\section{DISCUSSION}

\section{Morphology}

The spleen of the peccary was composed by the ventral, middle and dorsal regions and with colored red, similar to described by König and Liebich (2011) for swine. However, the literature has other definitions for the spleen's shape. Germinaro et al. (1997) studied the anatomicsurgical segmentation of the capybara spleen and described it as somewhat triangular, with fissures at the ventral and caudal borders that reveal the splenic lobes, different from the peccary whose parenchyma is smooth and fissure-free. Foz Filho et al. (2013) registered that the horse's spleen is shaped like a comma or scythe, whereas Meirelles et al. (2013), in their studies on the morphology of the alligator's spleen, described it as cone-like, thicker on the cranial section and tapering on the caudal one. In humans, Chaware et al. (2012) and Setty and Katikireddi (2013) described that the spleen has a wedge shape, but it may have tetrahedral, triangular or oval shape. These authors noted that spleen has two poles, two borders and two surfaces, as seen in the collared peccary.

The light microscopy, the spleen of the collared peccary has a thick capsule formed by a fine layer of the mesothelium, a thick conjunctive tissue, and by two to three layers of smooth muscles. Burke and Simon (1970) studied the spleen of Wistar rats by electronic microscopy and reported that the capsule is formed by a mesothelium layer and predominantly composed of fibroblast and collagen. The same authors failed to define the muscular tissue in the capsule and trabeculae since they found irregular cells that were similar to old fibroblasts and different from muscular cells, or rather, very different from that reported in the peccary. On the other hand, Cesta (2006) reports that the spleen capsule of rats is made up of fibroelastic and muscular tissues, with the most external layer made up of mesothelium cells similar to that in the peccary.

Banks (1991) report that the spleen capsule of domestic mammals is formed by conjunctive tissues and smooth muscular fibers. The literature describes the fibers as intertwining in carnivores, pigs, goats and ewes, whereas the muscular layers are perpendicular in horses and cattle (BACHA JÚNIOR; BACHA, 2003). In fact, they differ from reports on the peccary's muscular fibers that are parallel to the conjunctive tissue. They are perpendicular only in areas close to the trabeculae. Valli et al. (2002) also report that the dog's capsule and trabeculae are rich in muscular tissue and provide the dogs' organ with a rapid contraction, contrastingly to the peccary with little muscular tissue and few trabeculae, with less agility in contractions when needed.

The peccary's spleen parenchyma is divided into white and red pulps, as in other animals (BURKE; SIMON, 1970; BANKS, 1991; BACHA JÚNIOR; BACHA, 2003; MEIRELLES et al., 2013; SANTOS et al., 2013) and in humans (BISHOP; LANSING, 1982). In the marginal zone is found pericapillary macrophage sheaths, numerous in the peccary and very similar to those of the pig (BACHA JÚNIOR; BACHA, 2003).

Electronic microscopy of Wistar rats's spleen by Burke and Simon (1970) showed that the organ's white pulp is predominantly composed of lymphocytes in the midst of numberless reticular cells. The above made it impossible to identify the germination center characteristic of lymphatic sheaths, contrastingly to that reported in the peccary. Plasma cells, macrophages, erythrocytes and plaques may be encountered in the peripheral region, adjacent to the marginal zone. On the other 
hand, Bishop and Lansing (1982) studied the morphology of the human spleen and registered that the white pulp comprised two components, or rather, the periarterial lymphatic sheaths and the lymphatic nodules. The former are cylindrical and surround the arterial vases, similar to that in the peccary. The authors also mention that the cell constitution and extension of the components are dynamic, reflecting the spleen's antigen condition.

According to Burke and Simon (1970), Wistar rat's red pulp is formed by oblique sinusoids separated by cell cords, called cords of Billroth, or red pulp cords, which vary in thickness, and are made up of reticular cells, fibroblasts, leucocytes and particularly by macrophages. The authors also report that the cells commonly found in the red pulp are erythrocytes found in the sinusoids and cords, as registered in the peccary. Similarly, Saito et al. (1988), in their studies on rats, and Bishop and Lansing (1982), on humans, describe the red pulp as a tri-dimension network composed of splenic cords and venous sinusoids, with the former composed of reticular fibers and reticular cells associated to macrophages.

The peccary's spleen is characterized as an intermediary type with a great amount of white pulp, lower than the 'defense' type described in $\mathrm{mdx}$ mouse (SANTOS et al., 2013), in humans and in lagomorphs, and higher than the 'storage' type in the cat, dog and horse (BANKS, 1991). Few trabeculae may be found in the peccary and is similar to the spleen of pigs and ruminants (BANKS, 1991).

\section{Vascularization and anatomic-surgical segmentation.}

The peccary's lienal artery derives from the division of the celiac artery, and then penetrates the spleen, corroborating the literature on the pig (GONÇALEZ et al., 2003), cat (SILVA et al., 2012), ruminants, dog and horses (KÖNIG; LIEBICH, 2011), deer (AMADORI et al., 2012), opossum (SILVA et al., 2005) and rodents (CARVALHO et al., 1994; OLIVEIRA et al., 2012). However, Meirelles et al. (2013) in their research on alligators, report that the spleen's irrigation derives from the celiac artery through one of its branches, or rather, the cranial mesenteric artery which, involved in the lienal parenchyma at the surface and deep in the organ's central region, branches within the interior of the organ in lienal arteries, different from that in the peccary.

Reginato and Melo (2004) studied the anatomic-surgical segmentation of the white-lipped peccary's spleen and discovered that the lienal pedicle is divided into three extraparenchymal branches. This condition is not found in the collared peccary since its lienal vein does not have any extraparenchymal branches. Foz Filho et al. (2013) report that, similar to the collared peccary, the lienal artery of the horse lacks extraparenchymal division and penetrates directly into the hilum. Displacing itself into the organ's main axis, it emits segment branches towards the intestinal and gastric sides. On the other hand, Carvalhal et al. (2001), in their studies on the vascularization of cattle spleen, report that the lienal artery derives from two extra-hilum branches prior to penetrating the hilum, contrastingly to the collared peccary.

It is seen that many researchers are interested in determining the anatomic-surgical segmentation of the parenchymatose and tubular organs. In fact, Reginato and Melo (2004) classify the artery or vein respectively as arterial or venous segment that is specifically directed towards a determined territory. According to this definition, it may be said that there are several arterial and venous segments in the collared peccary.

The spleen of the latter is limited by the lienal artery, as reported in swine (SAMPAIO; SAMPAIO, 2006). The organ is divided in collared peccary into three great regions, namely, dorsal, medium and ventral regions. The dorsal section corresponds to that in which the vessels lie before the lienal vein on the left of the organ; the middle section lies between the lienal and the gastroepiploic vessels; the ventral section lies at the right, after the gastroepiploic vessels.

In terms of irrigation and based on arterial and venous vessels in the parenchyma, the peccary's spleen has three regions, namely, dorsal, medium and ventral, similar to the pig (SILVA; MARTINS, 2000), white-lipped peccary (REGINATO; MELO, 2004) and rabbit (PIRES et al., 2010). Further, Sampaio and Sampaio (2006) studying the lineal artery in pig, demonstrated that the latter is distributed throughout the spleen and is divided into two segments, or rather, a small dorsal segment and a ventral one featuring $83 \%$ of the organ, contrastingly to the collared peccary. Foz Filho et al. (2013) state that the horse's spleen is composed of the dorsal and ventral segments, of which the latter may be removed due to the lack of extraparenchymal branches. On the other hand, Melo et al. (2011) describe the deer's arterial segment and mention that the lienal artery discharges two to four extraparenchyma branches prior to its penetration into the hilum. Less frequently, the division only occurs after the penetration of the hilum. In this case the irrigated 
segments are named cranial, mid-cranial, midcaudal, caudal and hilum segments.

The collared peccary's lienal vein derives from several branches that intertwine, unite and drain the organ's ventral extremity. This vessel later received the left gastroepiploic vein, continued its rectilinear path within the splenic parenchyma and received several branches that drained the middle segment and then followed to the splenic hilum. Prior to this, the lienal vein also received venous branches which drained the dorsal segment, left the organ and united to the hepatic portal vein taking the spleen blood to the liver.

In the case of the white-lipped peccary, Reginato and Melo (2004) report that the lienal vein lies on the lienal artery and sometimes is intertwined after the initial bifurcation, an event not reported in the collared peccary. The same authors also register that the venous anatomic and surgical segments drain an independent territory by a segment vein, as reported in the collared peccary. Gupta et al. (1982) state that the smaller veins of the spleen drain their areas in two main affluents, at the right and at the left, or in three affluents, at the right, in the middle and at the left, giving rise to the lienal vein. The authors also report the possibility of the lienal vein as a single vein in the splenic parenchyma that crosses smaller veins as from its base to the apex, throughout its trajectory, similar to the system in the collared peccary.
Carvalhal et al. (2001) register that bovine lienal vein is a single vessel within a longitudinal path at a dorsal-ventral axis to which converge some 13 vessels of the cranial margin and 11 of the caudal margin. Further, Meirelles et al. (2013) report that the alligator's lienal veins drain the whole surface of the organ, with extensive intertwining. They are called lienal cranial, mid-cranial, middle and caudal veins and are different from those in the collared peccary. The authors state that, when these veins leave the spleen's parenchyma, they displace towards the hepatic portal vein, similar to what occurs in the collared peccary.

\section{CONCLUSION}

The spleen of the collared peccary has a tongue-like shape, red, without any limiting surface marks. It has a dorsal, middle and caudal segments identified by vascular distribution. The collared peccary's spleen is microscopically of the intermediate type, very similar to that of the pig.

Knowledge on the morphology and angioarchitecture of the collared peccary's spleen will contribute towards surgical procedures in wild species with a decrease in hemorrhage. Data should be taken into account when partial splenectomy is required.

RESUMO: O baço é um órgão linfoide secundário e com importância na clínica cirúrgica. Diante da inexistência de dados na literatura, este artigo estudou a morfologia e segmentação deste órgão em catetos. Foram utilizados 20 animais que vieram a óbito por causas naturais no Centro de Multiplicação de Animais Silvestres da Universidade Federal Rural do Semi-Árido, Mossoró-RN, Brasil. O baço foi coletado preservando-se o pedículo esplênico, pelo qual identificavam-se a artéria e a veia lienais. Fragmentos de quatro baços foram coletados para análise em microscopia de luz. Estes foram fixados em solução de paraformaldeído a $4 \%$ tamponado com fosfato de sódio $0,1 \mathrm{M}$, pH 7,4 e submetidos a técnicas histológicas de rotina. Os baços foram desidratados em concentrações crescentes de etanol; diafanizados em xilol; embebidos em parafina e obtidos cortes de $7 \mu \mathrm{m}$ e corados pela técnica de hematoxilina-eosina ou tricrômio de Gomori. A vascularização intraparenquimal de vinte baços foram analisadas através da perfusão de latex ou acetato de vinilite na artéria e veia lienais e logo o órgão foi fixado, respectivamente, em solução aquosa de formaldeído a $10 \%$ ou imersos em solução de ácido sulfúrico a 30\%. O baço do cateto apresentou-se como uma estrutura longa com forma similar a uma língua. Microscopicamente, o baço caracterizou-se como do tipo intermediário, possuindo quantidade considerável de polpa branca, com predominância da polpa vermelha e poucas trabéculas. A segmentação do baço em termos de irrigação apresentou três regiões distintas: dorsal, média e ventral, com a região dorsal passível de remoção cirúrgica. O conhecimento sobre a angioarquitetura e segmentação do baço de cateto contribuirá para a realização de procedimentos cirúrgicos nesta espécie silvestre e de grande importância quando se fizer necessário a esplenectomia parcial.

PALAVRAS-CHAVE: Anatomia. Artéria esplênica. Cirurgia. Esplenectomia. Órgão linfoide. 


\section{REFERENCES}

AMADORI, A.; BIRCK, A. J.; FILADELPHO, A. L.; GUIMARÃES, G. C.; PERES, J. A.; SOUZA, R. A. M. Origem e distribução da artéria celíaca em veado catingueiro (Mazama gouazoubira). Revista Científica Eletrônica de Medicina Veterinária, Garça, v. 10, n. 19, p. 1-10, 2012.

BACHA JÚNIOR, W. J.; BACHA, L. M. Atlas colorido de histologia veterinária. 2. ed. São Paulo: Roca, 2003. $457 \mathrm{p}$.

BANKS, W. J. Histologia veterinária aplicada. 2. ed. São Paulo: Manole, 1991. 629 p.

BISHOP, M. B.; LANSING, L. S. A. Correlative overview of normal and pathologic anatomy. Human Pathology, Philadelphia, v. 13, n. 4, p. 344-342, 1982.

BURKE, J. S.; SIMON, G. T. Eletron microscopy of the spleen. The American Journal of Pathology, Philadelphia, v. 58, n. 1, p. 127-155, 1970.

CARVALHAL, R.; SOUZA, W. M.; MIGLINO, M. A. Artéria e veia lienais de bovinos da raça Nelore. Brazilian Journal of Veterinary Research and animal Science, São Paulo, v. 38, n. 1, p. 9-12, 2001.

CARVALHO, M. A. M.; MIGLINO, M. A.; DIDIO, L. J. A. Ramificação e distribuição da artéria celíaca na cutia (Dasyprocta aguti). Brazilian Journal of Veterinary Research and Animal Science, São Paulo, v. 31, n. 3/4, p. 191-197, 1994. https://doi.org/10.11606/issn.1678-4456.bjvras.1994.52064

CESTA, M. F. Normal structure, function, and histology of the spleen. Toxicologic Pathology, Califórnia, v. 34, n. 5, p. 455-465, 2006. https://doi.org/10.1080/01926230600867743

CHAWARE, P. N.; BELSARE, S. M.; KULKARNI, Y. R.; UGHADE, J. Variational anatomy of the segmental branches of the splenic artery. Journal of Clinical and Diagnostic Research, New York, v. 6, n. 3, p. 336338, 2012.

CHRISTO, C. O. M. Estado da arte da cirurgia do baço, no início do século XXI. Revista do Colégio Brasileiro de Cirurgiões, Rio de Janeiro, v. 32, n. 5, p. 279-282, 2005.

CURY, F. S.; CENSONI, J. B.; AMBRÓSIO, C. E. Técnicas anatômicas no ensino da prática de anatomia animal. Pesquisa Veterinária Brasileira, Rio de Janeiro, v. 33, n. 5, p. 688-696, 2013.

FERNÁNDEZ-LLARIO, P.; PARRA, A.; CERRATO, R.; MENDOZA, J. H. Spleen size variations and reproduction in a Mediterranean population of wild boar (Sus scrofa). European Journal of Wildlife Research, Berlin, v. 50, n. 1, p. 13-17, 2004. https://doi.org/10.1007/s10344-003-0028-6

FOZ FILHO, R. P. P.; MARTIN, B. W.; LIMA, A. R.; MIGLINO, M. A. Horse spleen segmentation technique as large animal model of preclinical trials. Anais da Academia Brasileira de Ciências, Rio de Janeiro, v. 85, n. 4, p. 1411-1417, 2013.

GERMINARO, A.; BRANCO, E. R.; MIGLINO, M. A.; DIDIO, L. J. A.; SOUZA, W. M. Segmentação arterial do baço da capivara (Hydrochoerus hydrochoerus). Brazilian Journal of Veterinary Research and Animal Science, São Paulo, v. 34, n. 4, p. 196-202, 1997. https://doi.org/10.11606/issn.2318-3659.v34i4p196202

GONÇALEZ, P. O.; CARNEIRO E SILVA, F. O.; SEVERINO, R. S.; DRUMMOND, S. S. Origens e distribuições da artéria celíaca em fetos de suínos (Sus scrofa domesticus - Linnaeus, 1758) da linhagem "Rezende". Bioscience Journal, Uberlândia, v. 19, n. 1, p. 87-95, 2003. 
GUPTA, S. B.; SHARMA, S.; GUPTA, S. C.; GUPTA, D. Anatomical note. Venous segmentation in the spleen of the sheep. Journal of Anatomy, London, v. 135, n. 3, p. 657-659, 1982.

KÖNIG, H. E.; LIEBICH, H. G. Anatomia dos animais domésticos: Texto e atlas colorido. 4. ed. Porto Alegre: Artmed, 2011. 788 p.

MEIRELLES, R. B.; RODRIGUES, R. F.; MELO, A. P. F. Morfologia e vascularização do baço de jacaré (Caiman crocodilus yacare - Daudin, 1802). Biotemas, Florianópolis, v. 26, n. 4, p. 185-193, 2013.

MELO, A. P. F.; SOUZA, W. M.; RODRIGUES, R. F.; ALVES, F. R.; RICI, R. E.; GUERRA, R. R.; FAVARON, P. O.; MIGLINO, M. A.; DIDIO, L. J. Anatomical description of arterial segments of the spleen of deer. Anatomia, Histologia, Embryologia, Berlin, v. 40, n. 4, p. 243-248, 2011.

OLIVEIRA, G. B.; RODRIGUES, M. N.; SILVA, R. S. B.; PAULA, V. V.; CARVALHO, M. A. M.; OLIVEIRA, M. F. Origem e distribuição intraparenquimal da artéria hepática do preá (Galea spixii Wagler, 1831). Ciência Animal Brasileira, Goiânia, v. 13, n. 3, p. 377-381, 2012.

PIRES, T. S.; SANTOS, P. C. Z.; SILVA, J. R. C. P.; GRAZELLI FILHO, J.; FILADELPHO, A. L. Estudo comparado da vascularização arterial do baço de coelho (Oryctolagus cuniculus). Revista Científica Eletrônica de Medicina Veterinária, Garça, v. 8, n. 14, p. 1-11, 2010.

REGINATO, A. L.; MELO, A. P. F. Segmentação anátomo-cirúrgica em baços de queixada (Tayassu pecari Link, 1975). Brazilian Journal of Veterinary Research and Animal Science, São Paulo, v. 41, n. 4, p. 281285, 2004. https://doi.org/10.1590/S1413-95962004000400010

SAITO, H.; YOKOI, Y.; WATANABE, S.; TAJIMA, J.; KURODA, H.; NAMIHISA, T. Reticular meshwork of the spleen in rats studied by electron microscopy. The American Journal of Anatomy, Baltimore, v. 181, n. 3, p. 235-52, 1988. https://doi.org/10.1002/aja.1001810303

SAMPAIO, M. A. P.; SAMPAIO, B. P. S. M. Anatomical study and proportional analysis of the pig spleen arterial segments. Cells Tissues Organs, Basel, v. 182, n. 1, p. 32-34, 2006. https://doi.org/10.1159/000091716

SANTOS, A. C.; OLIVEIRA, D. M.; BERTASSOLI, B. M.; VIANA, D. C.; VASCONCELOS, B. G.; ASSIS NETO, A. C. Morphologic features from mdx mice spleens, used for duchenne muscular dystrophy studies. Journal of Morphological Science, São Paulo, v. 30, n. 1, p. 21-27, 2013.

SILVA, J. R. C. P.; MARTINS, M. R. F. B.; GUAZZELLI FILHO, J. Estudo da anatomia do baço do gambá (Didelphis albiventris). Veterinária Notícias, Uberlândia, v. 11, n. 2, p. 19-21, 2005.

SILVA, J. R. C. P.; MARTINS, M. R. F. B. Comparative study of arterial vascularization in swine spleen (Sus scrofa domesticus). Revista Chilena de Anatomia, Temuco, v. 18, n. 2, p. 223-226, 2000.

SETTY, S. R. S.; KATIKIREDDI, R. S. Morphometric study of human spleen. International Journal of Biological and Medical Research, New Delhi, v. 4, n. 3, p. 3464-3468, 2013.

SILVA, B. X.; ROZA, M. S.; BABINSKI, M. A.; PALHANO, H. B.; SCHERER, P. O.; ABIDUFIGUEIREDO, M. Ramos principais da artéria celíaca no gato doméstico: estudo aplicado à pesquisa experimental e à prática cirúrgica. Revista Brasileira de Ciência Veterinária, Niterói, v. 19, n. 3, p. 133-138, 2012. https://doi.org/10.4322/rbcv.2014.104

SOWLS, L. K. Javelines and other peccaries: Their biology, management and use. 2. ed. Tucson: Texas AandM University Press, 1997. 324 p.

TOLOSA, E. M. C.; BERMER, O. A.; FREITAS NETO, A. G. Manual de técnicas para histologia normal e patológica. 2. ed. Barueri: Manole, 2003. 341 p. 
VALLI, V. E.; MCGRATH, J. P.; CHU, I. Hematopoietic system. In: Haschek, W. M.; Rousseaux, C. G.; Wallig, M. A. (Eds). Handbook of toxicologic pathology. vol. 2. San Diego: Academic Press, 2002. p. 647-679. https://doi.org/10.1016/B978-012330215-1/50041-7

WANG, X.; WANG, M.; ZHANG, H.; PENG, B. Laparoscopic partial splenectomy is safe and effective in patients with focal benign splenic lesion. Surgical endoscopy, New York, v. 28, n. 12, p. 3273-3278, 2014.

WU, Z.; ZHOU, J.; PANKAJ, P.; PENG, B. Comparative treatment and literature review for laparoscopic splenectomy alone versus preoperative splenic artery embolization splenectomy. Surgical endoscopy, New York, v. 26, n. 10, p. 2758-2766, 2012. 